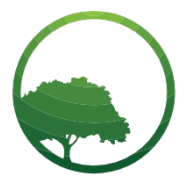

Research in Business \& Social Science

IJRBS VOL 8 NO 6 ISSN: 2147-4478

\title{
Influence of intellectual stimualtion on employee engagement in parastatals in the energy sector in Kenya
}

\author{
Change Doris Otieno ${ }^{a^{*}}$, Teresia Linge ${ }^{b}$, Damary Sikalieh \\ ${ }^{a, b, c}$ Chandaria School of Business, United States International University-Africa, Nairobi, Kenya
}

\author{
A R T I C L E IN F O \\ Article history: \\ Received 20 August 2019 \\ Accepted 15 September 19

\section{Keywords:} \\ Intellectual Stimualtion \\ Employee Engagement \\ Parastatals \\ Energy Sector \\ Kenya \\ JEL Classification: \\ O15 \\ P36
}

Received in revis. form 12 Sept. 2019

\begin{abstract}
A B S T R A C T
Employee engagement continues to pose a challenge to parastatals. Consequently, governments have adopted the transformational leadership style as an effective method of enhancing employee engagement. Nevertheless, it is still unknown whether the establishment of transformational leadership dimensions has boosted employee engagement in the Kenyan energy sector parastatals. The objective of this study was to investigate the influence of intellectual stimulation on employee engagement in parastatals in the energy sector in Kenya. Also, the study sought to determine the moderating influence of employee motivation on the relationship between intellectual stimulation and employee engagement.This study targeted the 10 parastatals within the energy sector in Kenya with a population of 315 middle-level managers. The study adopted a positivist research philosophy to examine the influence on intellectual stimulation on employee engagement anddata was collected using structured questionnaires. A correlational research design was conducted with the purpose of determining the strength of the relationship between parameters of intellectual stimulation and employee engagement.The findings showed that employee engagement has a statistical significant relationship with creativity and innovation, $r(166)=0.540, p<0.01$; job design, $r(166)=0.452, p<0.01$ and employee involvement, $r(166)=0.512, p<0.01$. Multiple linear regression analysis revealed that employee motivation positively and significantly moderates the relationship between intellectual stimulation and employee engagement, $R^{2}=.409, F(2,159)=55.115, p<.05 ; \beta=0.259, p<.01$. The study concluded that creativity and innovation, job design, employee involvement, and employee motivation positively enhance employee engagement.
\end{abstract}

\section{Introduction}

Organizations continue to experience difficulties in trying to achieve employee engagement (Iqbal, Khan \& Iqbal, 2012). The sustainability of corporate industries is pegged on increasing profits from current capabilities, while acknowledging the dynamic state of the business environment (Kortmann, Gelhard, Zimmermann, \& Piller, 2014). To achieve organizational success, leaders persistently strive to increase the engagement levels of their employees (Kortmann et al., 2014). Farndale and Murrer (2015) defined employee engagement as when employees harness themselves physically, cognitively, and emotionally while completing daily tasks. To achieve organizational vitality, survival and profitability, employee engagement must be achieved (Albercht, Bakker, Gruman, Macey, \& Saks, 2015). Further to this, employee engagement within organizations results in employee productivity, customer satisfaction and increased revenues (Vandenabeele, 2014). Reasearch has shown that globally, only 13\% of employees are fully engaged, negatively affecting organizations (Bersin, 2014). In Africa, Nguwi (2011) established that almost three quarters of the economically active population in Zimbabwe has a low level of engagement. Recently, most companies have been focusing intensely on employee engagement (SHRM, 2013). According to Gerst (2013), American firms spend more than 720M USD annually to improve on employee engagement. Also, IBM Software (2014) estimated that $90 \%$ of their global survey clients conduct employee engagement surveys to try and improve levels of engagement.

\footnotetext{
* Corresponding author. Tel: +254722888210 ORCID ID: 0000-0002-9997-6788
} Peer review under responsibility of Bussecon International Academy. (C) 2019 Bussecon International. Hosting by SSBFNET- Center for Strategic Studies in Business \& Finance. All rights reserved. https://doi.org/10.20525/ijrbs.v8i6.506 
In theory, the leadership style adopted within an organization has a great impact on employee engagement. According to Swathi (2013), leaders, in general, play an important role in creating the right context for employees to become engaged. Popli and Rizvi (2016) pointed out that the leader's behavior influences employee engagement resulting to organizational efficiency. A critical element to building confidence and increasing employee engagement, is to have people at the top who can inspire belief in the organization's future (Jensen, 2018). Leaders who ensure that employees know what to expect, have the resources to complete their work, are allowed to participate in growth, receive feedback and are encouraged to give their contribution, have a highly engaged workforce (Saumya \& Ritu, 2015).

Further research has shown that transformational leadership has a positive and significant relationship with employee engagement (Kaul, 2017). Transformational leadership style has four dimensions, namely idealized influence, inspirational motivation, intellectual stimulation, and individualized consideration (Schuck \& Herd, 2012). This study focused on intellectual stimulation. This represents the capacity of a leader to encourage others to be creative in looking at ancient problems in novel ways, and to create an environment which is tolerant (Zubair, Bashir, Abrar, Baig \& Hassan, 2015). This study looked at three parameters of intellectual stimulation namely; creativity and innovation, job design and employee involvement and how they influence employee engagement in parastatals in Kenya.

Parastatals in Kenya have experienced a series of challenges leading to some of them winding up or undergoing privatization (Miringu \& Muoria, 2011). Also, the public sector in Kenya has been plagued by poor performance hindering sustainable economic growth (Ogola \& Nzulwa (2018). Recently, there has been a gradual switch from transactional to transformational leadership within corporations (Asfar, Badir, Saeed \& Haffez, 2017). The Kenyan government through the Kenya Public Investment Committee (PIC) and The Presidential Taskforce on Parastatal Reforms (PTPRs) office has been instilling transformational leadership in the parastatals with the aim of improving the services rendered, employee engagement and organizational performance (Gok, 2013). Despite this, most of the parastatals have failed to achieve their targets and their results indicate both successes and failures (GoK, 2013). This shows that the influence of transformational leadership on employee engagement is still ambiguous. According to Batista-Taran, Shuck, Gutierrez and Baralt (2013) only a handful of studies have investigated this relationship. Also, other researchers have recommended more studies on the effects of the four dimensions of transformational leadership on employee outcomes (Saboe, Taing, Way \& Johnson, 2015). In addition, there is need for more studies on this subject as a priority, given contradictory research results on how transformational leadership style influences employee engagement (Mozammel \& Haan, 2016).

Despite the popularity of intellectual stimulation throughout numerous organizations, limited research exists in identifying potential issues in the implementation of this transformational leadership dimension within government entities in Kenya (Ndwiga \& Ngaithe., 2016). In this study, intellectual stimulation was measured in terms of creativity and innovation, job design and employee involvement. Mafini (2015) suggested that more studies should be carried out on the influence of innovation within organizations in various geographical regions. Also, job design continues to receive minimal attention from corporations and policy makers as an enhancer of engagement compared to other management concepts (Truss, 2012). There is an absence of knowledge for employers on the necessary principles of job design and the important factors that need to be considered when designing highly engaging jobs. Further to this Kariuki and Makori recommend that other studies should be conducted to investigate the influence of job design on employee engagement, specifically in the Kenyan context. In addition, Irawanto (2015) suggested that the influence of employee involvement on decision making should be investigated on larger samples. Also, Wachira (2013) recommends that further research should be conducted on employee engagement as this would provide specific details on how management can improve on organizational outcomes This study aims to fill these gaps by examining the influence of intellectual stimulation on employee engagement in parastatals in the energy sector in Kenya.

Research has shown that the prosperity of a leader is influenced by his capacity to motivate employees to enhance their commitment, efforts, practice, engagement and persistence (Alghazo \& Al-Anazi, 2016). Studies have shown that a positive relationship exists between transformational leadership and employee motivation (Susilo, 2018). Thus, having a motivated workforce is one of the most fundamental outcomes of transformational leadership (Gennaro, 2018). Employees who are inclined towards motivation achieve both personal and organizational goals. Elsele, Gronhert, Bausaert and Segers (2013) in their study found that motivated employees express more commitment to their work. Therefore, this study examined the moderating influence of employee motivation on the relationship between intellectual stimulation and employee engagement.

The following hypotheses were used in this study.

$\mathrm{H}_{01}$ : Creativity and innovation has no significant influence on employee engagement in parastatals in the energy sector in Kenya.

$\mathrm{H}_{02}$ : Job design has no significant influence on employee engagement in parastatals in the energy sector in Kenya.

$\mathrm{H}_{03}$ : Employee involvement has no significant influence on employee engagement in parastatals in the energy sector in Kenya.

$\mathrm{H}_{04}$ : Employee motivation does not significantly moderate the relationship between intellectual stimulation and employee engagement in parastatals in the energy sector in Kenya. 


\section{Literature Review}

This study was based on Bass' (1985) Transformational Leadership Theory. This theory was first established by leadership expert McGregor Burns in 1978 and further developed by Bass in 1985. According to Gabbar, Honarmand \& Abdelsalam (2014) transformational leadership emphasizes on guiding employees to be more involved in achieving their organizational targets. The Transformational Leadership Theory posits that the strength of the vision and personality of such leaders is able to inspire followers to change their expectations, perceptions and motivation to work leading to achievement of organizational goals (Izlem \& Omer, 2015). This theory posits that when leaders apply behaviors related to the four dimensions of transformational leadership, the result is higher engagement, effectiveness and extra effort from employees (Hawkes, Biggs \& Hegerty, 2017).

Transformational leaders help their followers to rise above their own self-interests and give extra effort in order to achieve the organization's mission (Bass, 1985). Such leaders can elicit this extra-ordinary performance on followers through behaviors that motivate exceptional performance (Conger, 2014) leading to organizational performance. Both Burns (1978) and Bass's (1985) theories explain the interaction between employees and management especially how the relationship between employee and management is managed in ways that ultimately lead to employees going beyond their self-interest in support of organizational targets. By providing intellectual stimulation, transformational leaders motivate their followers to be innovative in solving problems and providing solutions (Bass, 1990). This study hypothesized that if leaders are able to demonstrate intellectual stimulation behaviors, the outcome will be improved employee engagement levels.

\section{Intellectual stimulation and employee engagement}

Intellectual stimulation has been found to be predictive of higher levels of follower innovative work behavior (Abbas, Iqbal, Waheed \& Riaz, 2012). An analysis of this variable indicates that intellectual stimulation results in the empowerment of followers by encouraging them to provide solutions to challenges encountered in the line of duty through creativity, job characteristics and employee involvement (Smothers, Doleh, Celuch, Peluchette \& Valadares, 2016). The growing of Generation Y employees in Malaysia has raised concerns about how to engage and motivate this cohort. Mansor, Mun, Farhana and Tarmizi. (2017) found a positive relationship between intellectual stimulation and employee engagement among Generation Y employees based in Selangor and Klang Valley. Anjali and Anand (2015) established that intellectual stimulation encourages employee organizational commitment. In Africa, Gautam and Enslin (2019) found a significantly positive relationship between intellectual stimulation and work engagement within the South African automotive retail industry. In Kenya, Datche and Mukulu (2015) examined the effects of transformational leadership on employee engagement within the civil service. Data was collected from employees from 18 top performing state organizations. Structured questionnaires were used to collect data from a sample selected through stratified random sampling. The findings revealed that intellectual stimulation significantly predicts employee engagement. Also, Ndisya and Juma (2016) found that intellectual stimulation has a positive relationship with employee performance among Safaricom Limited employees in Kenya. In this study, intellectual stimulation was measured using; creativity and innovation, job design and employee involvement.

Leaders have the ability to stimulate and facilitate organizational creativity (Amabile, 2013). Transformational leaders intellectually stimulate their followers' efforts to be innovative and creative by questioning assumptions, reframing problems and approaching old situations in new ways (Sharma, 2016). The questioning ability of an intellectually stimulating leader enables followers to regenerate their intellectual inquisitiveness, engage their imagination to develop new solutions and unique concepts (Doran \& Ryan, 2017). Tao (2012) suggested that for employees to be innovative their executives should create an innovative atmosphere that will allow creativity. Ghodratolla, Mahdi, Ahmad and Reza (2013) found that creativity positively relates with employee engagement. When employees are disengaged, there is a decline in the standards of their work, a lack of desire to learn and an overall drop-off in effort. In Africa, Mafini (2015) found that innovation within organizations enhances the performance of employees in South Africa. In Kenya, Wambui, Kahuthia and Gakenia (2018) found that innovation strategies within organizations increased organizational performance. Therefore, to reawaken their drive, employees must be fascinated by their assignments and should be challenged by new tasks and projects (Murage, K’Aol \& Njenga, 2017).

There has been an increasing amount of research examining how to combine different elements of jobs to optimize the engagement of employees on one hand, and to optimize the organizational productivity and performance on the other. Research has shown that the linkage between leadership styles and employee engagement is influenced by several factors: characteristics of the organization, the employees and the job (Jones, Haslam \& Haslam, 2017). The allocation of high quality jobs is viewed as a fundamental lever in boosting employee positive outcomes and well-being (Grote \& Guest, 2016). According to Aroosiya and Ali (2014) most productivity problems reside on how jobs are designed based on the environment of the organization. A number of studies have shown that employees' experiences in their everyday work have a direct influence on their engagement levels as well as their personal efficiency (Shantz, Alfes, Bailey \& Soane, 2013). A study by Truss (2012) revealed that job design has a positive relationship with employee engagement. Conversely, when employees are assigned challenging and interesting roles, they are inspired and motivated to devote their efforts in their work, and it is the dedication of these energies that researchers have linked to employee engagement (Crawford, Rich, Buckman \& Bergeron, 2013). In Africa, Obianuju and Nsoedo (2015) found a positive relationship between job design and employee engagement in Nigeria. Dull and monotonous work roles will lower employees' motivation and engagement levels. Kariuki and Makori (2015) found that how jobs are designed significantly predicts employee engagement in Kenyan private universities. 
Little information is available on the leading principles of job design and the necessary factors that need to be considered while designing jobs that are engaging in the Kenyan context. Thus, the question for business owners and managers is: in what way can jobs be designed for ultimate effect? The aim of this research was to the bring out evidence demonstrating the influence of job design on engagement of middle level managers within parastatals in the energy sector in Kenya, and to equip employers with knowledge into how to design jobs that will maximize levels of engagement.

The present-day forward-looking corporation does not hide vital decisions from employees. Intellectually stimulating leaders encourage employee involvement within the organization (Bass, 2008). The employees are trusted and involved in decision making processes at all levels. Employee involvement processes allow the employees to directly or indirectly influence the decisions of the firm (Irawanto, 2015). To create trust and confidence to the employees, leaders must keep employees informed about the business performance and company's plans. In Sri Lanka, Thavakumar and Evangeline (2016) found that employee involvement and participation significantly and positively influences employee engagement among insurance companies' employees in Batticaloa District. Employees must be involved if they are to commit to improving their work behavior (Appelbaum et al., 2013). This is because, employees who are involved in decision making have a sense of belonging and ownership to the organization. In Africa, Ike, Ezeh and Etodike (2017) investigated how workers' involvement and decision-making affects organizational citizen behavior in Nigeria. The data was collected from private companies with a total population of 496 staff. The findings of the analysis revealed that when workers are involved in organizational decision-making process there is a significant increase on organizational citizenship behavior. In Kenya, Odero and Makori (2018) found that employee involvement influences the performance of public universities lecturers. Also, Butali and Njoroge (2015) noted that most firms have discovered that employee involvement is important to employee engagement hence it is strategically necessary for prosperity and the socialization of the organization.

Contrary to these findings, Osmani, (2016) argued that participative approach is un-preferable in the presence of complex choices, varied and complicated in nature. In addition, management appears weak and loses its power by encouraging employee voice. This is a situation where task similarity is very high; the environment is dynamic thus discouraging the participation of employees. Given these contradictory findings, this study aimed to investigate the influence of employee involvement on employee engagement. The review of literature shows that most studies found that intellectual stimulation positively influences employee engagement. The issue presented is that a large number of these studies are foreign and do not cover the Kenyan context.

\section{Employee motivation, intellectual stimulation and employee engagement}

Research has shown that the effectiveness of leadership behaviors depends on the strength of the moderating variables applied (Humborstad, Nerstad \& Dysvik, 2014). According to Naile and Selesho (2014) motivation is one of the moderating variables that strengthen the effectiveness of the relationship between leadership behaviors and employee engagement. Employee motivation is considered as a force that drives the employees toward attaining specific goals and objectives of the organization (Ganta, 2014). It has been employed in previous studies as a moderator to demonstrate whether it can predict the strength and the direction of relationships between variables. Soliha, Dharmmesta, Purwanto and Syahlani, (2014) and Roos and van Eeden (2013) are examples. This study examined whether employee motivation moderates the relationship between intellectual stimulation and employee engagement. This section reviews literature on the influence of extrinsic and intrinsic motivation on the relationship between intellectual stimulation and employee engagement.

The leadership within an organization is tasked with the important role of enhancing the performance and engagement of its followers by motivation (Zameer, Ali, Nisar \& Amir, 2014). Most scholars have defined a leader as someone who motivates the followers to achieve a common goal (Sougui, Bon, Mahamat \& Hassan, 2016). Therefore, it is not possible for an organization to be successful without a good leader, who highly motivates and engages followers. As noted from numerous surveys carried out by HR firms, managers greatly influence the engagement of their employees by motivation (Mohanan, Sequira \& Kumar, 2012). Transformational leadership has been consistently claimed to be particularly effective than the other leadership styles by appearing to enable leaders to motivate their followers (Kharabe \& Joseph, 2016). Further to this, Aunjum, Abbas and Sajid (2017) found that, leaders who are intellectually stimulating have a highly motivated workforce within the banking sector of Pakistan. In addition, Susilo (2018) found that transformational leadership dimensions are good predictors of employee motivation. Employee motivation in this study was measured using extrinsic and intrinsic motivation.

Motivation of employees is perceived to have a positive impact on employee outcomes, yet many organizations have not realized this. Singh (2016) found that the use of extrinsic rewards to motivate employees can be justified by using Abraham Maslow's hierarchy of needs ranging from physiological needs to self-actualization needs. Extrinsic rewards refer to all categories of financial benefits, tangible services and benefits that an employee receives as part of employment relationship with the organization (Irshad, 2016). Lawler (2003) stated that there are two aspects that decide how much a reward is attractive, the quantity of the reward and the weight an employee gives to a specific reward. Employees are certainly closer to their organizations and perform better, when they receive healthier rewards and recognition. Yousaf, Latif, Aslam and Saddiqui (2014) agreed that financial incentives are indeed effective in motivating employees. However, Khuong and Nguyen (2016) found that financial reward systems have short term motivational boosts and therefore managers should combine them with non-financial compensation for long term impact. More studies have reported positive effects of transformational leadership dimensions on employee attitudes and organizational outcomes through extrinsic rewards. A study carried out by Sharma and Krishnan (2012) investigated the relationship between transformational 
leadership and pay satisfaction and employee engagement among 93 employees across different domains. The findings established that pay satisfaction moderated the relationship between transformational leadership dimensions and employee engagement.

Leaders play an important role to ensure that their employees are intrinsically motivated. Intrinsic motivation is defined as a psychological force that impels employees to perform based on an aspect of nature that is expressed under certain conditions (Gyamfi, 2014). Recent studies have found that employees would most value a job that has aspects that are important and meaningful to them rather than extrinsic rewards (Smith, Joubert, Karodia, 2015). According to Ryan and Deci (2017) when high levels of intrinsic motivation are provided employees, may lessen their need for extrinsic rewards. Leaders play an important role to ensure that their employees are intrinsically motivated. Jensen and Bro (2017) found that transformational leadership dimensions play an important role in enhancing intrinsic motivation in organizations.

Several studies have been conducted to investigate the moderating influence of intrinsic motivation on the relationship between transformational leadership dimensions and employee engagement. Intellectually stimulating leaders do not impose their own ideas judiciously and certainly on subordinates but rather allow employees autonomy to make decisions in their daily processes (Fauji \& Utami, 2013). Dysik and Kuvaas (2014) conducted a study to examine the moderating role of intrinsic motivation on the relationship between job autonomy and employee performance. A survey was conducted on 302 employees representing different Norwegian organizations from the service industry. The findings showed that intrinsic motivation strengthens the relationship between perceived job autonomy and performance. In Indonesia, Lee and Hidayat (2018) found that intrinsic motivation moderates the relationship between all dimensions of transformational leadership and employee performance. In Africa, Alalade and Oguntodu (2015) revealed that leaders who enhanced intrinsic motivation have a highly performing work force in Nigeria. In Ghana, Gyamfi (2015) found that intrinsic motivation is positively correlated with employee positive outcomes. In Zimbabwe, a study conducted by Masvaure, Ruggunan and Maharaj (2014) found that employees who are intrinsically motivated are inclined to work with zeal, passion with great interest in their work roles. Most of these studies revealed that employee motivation significantly moderates the relationship between intellectual stimulation and employee engagement. The gap presented is that most of these studies differ from the present study in context and focus. The previous research has not specifically covered the correlation between employee motivation, intellectual stimulation and employee among middle level managers in parastatals within the energy sector in Kenya. Therefore, this provides a gap, hence necessitating this research.

\section{Research and Methodology}

This study adopted a positivism research philosophy and a descriptive correlational research design because the study was quantitative in nature and was aimed at testing hypothesis. The population of the study consisted of 315 middle level managers from parastatals within the energy sector in Kenya. A sample size of 176 was drawn using stratified random sampling.

$\mathrm{n}=\mathrm{N} /(1+\mathrm{N}(\mathrm{e}) 2 \mathrm{t}$

Where $\mathrm{n}$ is the sample size, $\mathrm{N}$ is the population size and $\mathrm{e}$ is the level of precision

$\mathrm{n}=315(1+315(0.05 * 0.05))=176$ respondents

Following stratification, simple random sampling was applied to choose the middle level managers from each stratum depicted in the total population. The strata for petroleum comprised $26.3 \%$, renewable energy $5.7 \%$, electricity $64.7 \%$ and regulatory $3.2 \%$ of the target population. Stratified sampling was appropriate since the parastatals were of various categories hence they were divided into five different strata. Data was collected using self-administered questionnaires. Furthermore, inferential data analysis methods were used.

\section{Result and Discussion}

This section presents results and findings of the study

\section{Demographic information}

Most of the middle managers were male (64.5\%) while $35.5 \%$ were female. A majority of the respondents had worked in their organizations for more than 11 years $(57.3 \%)$ while $69.9 \%$ of the respondent were above 40 years of age.

\section{Correlation between intellectual stimulation and employee engagement}

The strength of the relationship between intellectual stimulation and employee engagement is shown by a correlation analysis. The study sought to determine the correlation between intelelctual stimulation and employee engagement. The results of the correlational analysis presented in Table 4.1 revealed that all parameters of intellectual stimulation were positively and significantly correlated with employee engagement. From the results in Table 1, it is clearly demonstrated that employee engagement significantly correlates with creativity and innovation, $\mathrm{r}(166)=0.540, \mathrm{p}<0.01$; job design, $\mathrm{r}(166)=0.452, \mathrm{p}<0.01$ and employee involvement, $\mathrm{r}(166)=$ $0.512, \mathrm{p}<0.01$. 
Table 1: Correlation between Intellectual Stimulation and Employee Engagement

\begin{tabular}{|c|c|c|}
\hline \multicolumn{3}{|c|}{ Correlation } \\
\hline & & Employee Engagement \\
\hline \multirow[t]{3}{*}{ Creativity and Innovation } & Pearson Correlation & $.540^{* *}$ \\
\hline & Sig. (2-tailed) & .000 \\
\hline & $\mathrm{N}$ & 166 \\
\hline \multirow[t]{3}{*}{ Job Design } & Pearson Correlation & $.452^{* *}$ \\
\hline & Sig. (2-tailed) & .000 \\
\hline & $\mathrm{N}$ & 166 \\
\hline \multirow[t]{3}{*}{ Employee Involvement } & Pearson Correlation & $.512^{* *}$ \\
\hline & Sig. (2-tailed) & .000 \\
\hline & $\mathrm{N}$ & 166 \\
\hline
\end{tabular}

Source: Authors

\section{Multiple linear regression analysis and hypothesis testing for creativity and innovation and employee engagement}

Multiple linear regression was conducted with the purpose of determining the level and direction of the relationship between creativity and innovation and employee engagement.

\section{Regression model summary for creativity and innovation and employee engagement}

Table 2 (a): Model Summary for Creativity and Innovation and Employee Engagement

\begin{tabular}{lrrrr}
\hline \multicolumn{3}{c}{ Model Summary } & \\
\hline Model & R Square & Adjusted R Square & Std. Error of the Estimate \\
\hline 1 & $.540^{\mathrm{a}}$ & .291 & .287 & .359 \\
\hline a. Predictors: (Constant), Creativity and Innovation & & & \\
\hline
\end{tabular}

The results indicate that creativity and innovation explained a significant proportion of the variance in employee engagement, ${ }^{2}=.291$. Findings are shown in Table 2 (a). This implies that $29.1 \%$ of the prorportion in employee engagement of middle level managers can be explained by creativity and innovation. The $R$ value of 0.540 indicates that creativity and innovation, contributed to $54 \%$ change in the dependent variable, employee engagement of middle level managers.

Regression ANOVA for creativity and innovation and employee engagement

Table 2 (b): Regression ANOVA for creativity and Innovation and Employee Engagement

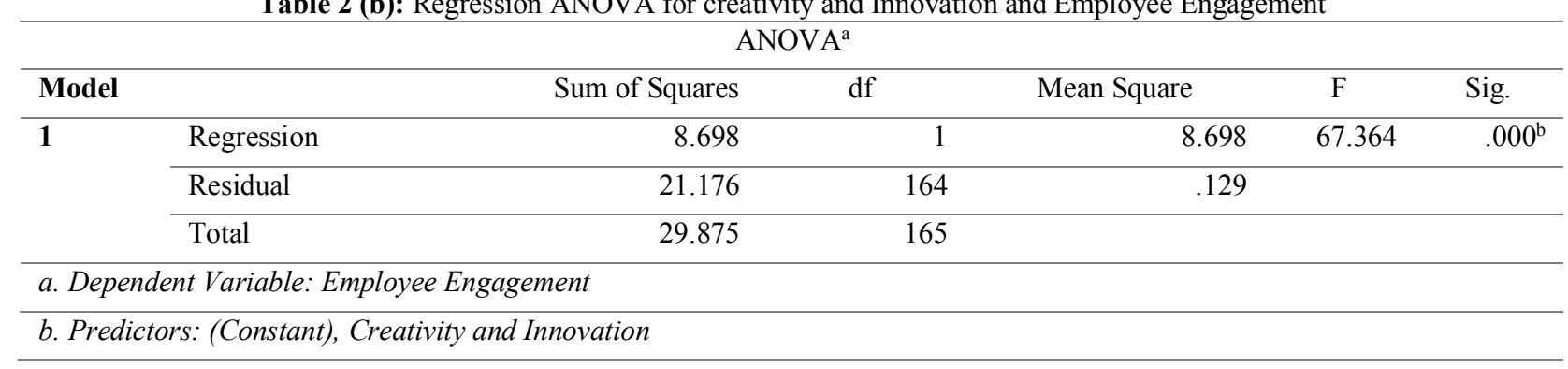

The results in Table 2 (b) point out that the model was statistically significant in linking the data. The results revealed that creativity and innovation statistically and significantly predicted employee engagement, $F(1,165)=67.364, p<.05$. Therefore, the model was statistically significant in hypothesis testing of $\mathrm{H}_{01}$ : Creativity and Innovation has no significant influence on employee engagement in parastatals in the energy sector in Kenya.

\section{Regression coefficients for creativity and innovation and employee engagement}

These results in Table 2 (c) indicate that creativity and innovation positively and significantly predicted employee engagement, $\beta=$ $.403, t(165)=8.208, p<.01$. This implied that a unit increase in creativity and innovation would lead to an increase in employee 
engagement among the middle level management in parastatals in the energy sector in Kenya by 0.403 units.

Table 2 (c): Regression Coefficients for Creativity and Innovation and Employee Engagement

\begin{tabular}{|c|c|c|c|c|c|c|}
\hline \multicolumn{7}{|c|}{ Coefficients $^{\mathrm{a}}$} \\
\hline \multirow{2}{*}{\multicolumn{2}{|c|}{ Model }} & \multicolumn{2}{|c|}{ Unstandardized Coefficients } & \multirow{2}{*}{$\begin{array}{c}\text { Standardized Coefficients } \\
\text { Beta }\end{array}$} & \multirow[t]{2}{*}{$\mathrm{t}$} & \multirow[t]{2}{*}{ Sig. } \\
\hline & & B & Std. Error & & & \\
\hline \multirow[t]{2}{*}{1} & (Constant) & 2.406 & .189 & & 12.747 & .000 \\
\hline & Creativity and Innovation & .403 & .049 & .540 & 8.208 & .000 \\
\hline
\end{tabular}

The results of the multiple linear regression in Tables 4.2 (a), (b) and (c) show that creativity and innovation significantly predicted employee engagement of middle level managers as shown by $R^{2}=.291, F(1,165)=67.364, p<.0 .1, \beta=0.403, t(165)=8.208, p<$ .01 , hence the null hypothesis, $\mathrm{H}_{01}$ : Creativity and innovation has no significant influence on employee engagement in parastatals in the energy sector in Kenya, was rejected.

\section{Multiple linear regression and hypothesis testing for job design and employee engagement}

\section{Regression model summary for job design and employee engagement}

The results indicate that job design explained a significant proportion of the variance in employee engagement $2=.204$. Findings are shown in Table 3 (a). This implies that $20.4 \%$ of the prorportion in employee engagement of middle level managers can be explained by job design. The $R$ value of 0.452 indicates that the predictor variable which is job design, contributed to $45 \%$ change in the dependent variable, employee engagement of middle level managers.

Table 3 (a): Regression Model Summary for Job Design and Employee Engagement

\begin{tabular}{lcccc}
\hline \multicolumn{5}{c}{ Model Summary } \\
\hline Model & & R Square & Adjusted R Square & Std. Error of the Estimate \\
\hline $\mathbf{1}$ & $.452^{\mathrm{a}}$ & .204 & .199 & .381 \\
\hline a. Predictors: (Constant), Job Design & & & & \\
\hline
\end{tabular}

\section{Regression ANOVA for Job Design and Employee Engagement}

The study results in Table 4.3 (b) point out that the model was statistically significant in linking the data. The results reveal that job design statistically and significantly predicted employee engagement, $F(1,165)=41.998, p<.05$. Therefore, the model was statistically significant in hypothesis testing of $\mathrm{H}_{02}$ : Job design has no significant influence on employee engagement in parastatals in the energy sector in Kenya.

Table 3 (b): Regression ANOVA for Job Design and Employee Engagement

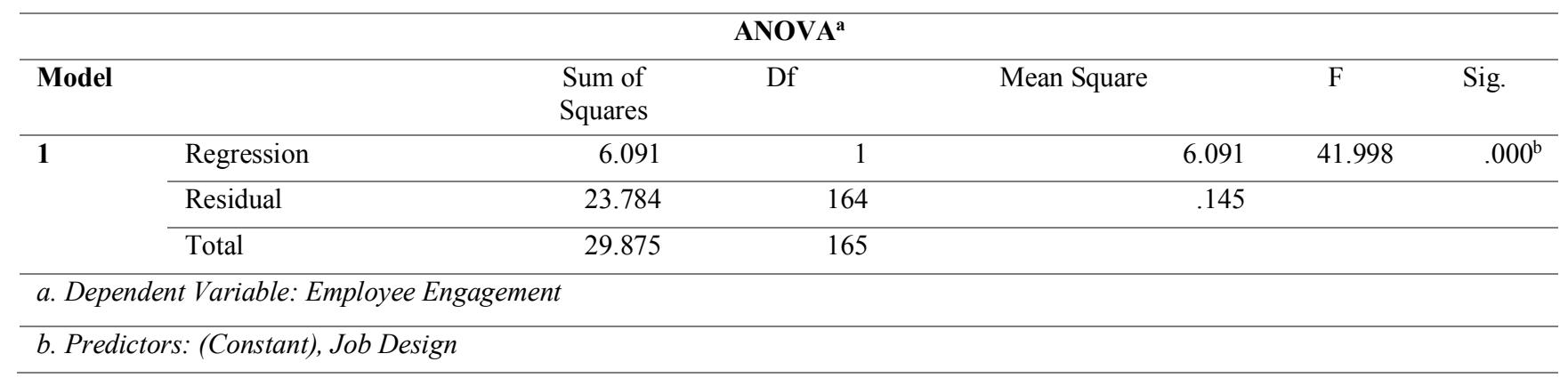




\section{Regression coefficients for job design and employee engagement}

Table 3 (c): Regression Coefficients for Job Design and Employee Engagement

\begin{tabular}{|c|c|c|c|c|c|c|}
\hline \multicolumn{7}{|c|}{ Coefficients $^{\mathbf{a}}$} \\
\hline \multirow{2}{*}{\multicolumn{2}{|c|}{ Model }} & \multicolumn{2}{|c|}{$\begin{array}{c}\text { Unstandardized } \\
\text { Coefficients }\end{array}$} & Standardized Coefficients & $\mathrm{t}$ & Sig. \\
\hline & & B & Std. Error & Beta & & \\
\hline \multirow[t]{2}{*}{1} & (Constant) & 2.517 & .221 & & 11.365 & .000 \\
\hline & Job Design & .361 & .056 & .452 & 6.481 & .000 \\
\hline
\end{tabular}

These results in Table 4.3 (c) indicate that job design positively and significantly predicted employee engagement, $\beta=.361, t(165)$ $=6.481, p<.01$. This implied that a unit increase in job design would lead to an increase in employee engagement among the middle level management in parastatals in the energy sector in Kenya by 0.361 units. The results of the multiple linear regression in Tables 4.3 (a), (b) and (c) show that job design significantly predicted employee engagement of middle level managers as shown by $R=$ $.204, F(1,165)=41.998, p<.0 .05, \beta=.361, t(165)=6.481, p<.01$, hence the null hypothesis $\mathrm{H}_{02}:$ Job design has no significant influence on employee engagement in parastatals in the energy sector in Kenya, was rejected.

\section{Multiple regression and hypothesis testing for employee involvement and employee engagement}

Regression model summary for employee involvement and employee engagement

The findings in Table 4 (a) indicate that employee involvement explained 26.2\% variation in employee engagement among middle level managers in parastatals in the energy sector in Kenya, $R^{2}=.262$. The $R$ value of 0.512 indicates that the predictor variable, employee involvement, contributes to $51 \%$ change in the dependent variable, employee engagement of middle level managers.

Table 4 (a): Regression Model Summary for Employee Involvement and Employee Engagement

\begin{tabular}{lcccr}
\hline \multicolumn{5}{c}{ Model Summary } \\
\hline Model & $\mathrm{R}$ & R Square & Adjusted R Square & \multicolumn{2}{c}{ Std. Error of the Estimate } \\
\hline $\mathbf{1}$ & $.512^{\mathrm{a}}$ & .262 & .257 & .367 \\
\hline a. Predictors: (Constant), Employee Involvement & & & \\
\hline
\end{tabular}

Regression ANOVA for Employee Involvement and Employee Engagement.

Table 4 (b) presents the results of the regression ANOVA for employee involvement and employee engagement and these findings indicate that the model was statistically significant in linking employee involvement and employee engagement, $F(1,165)=58.203$, $p<.05$. Thus, the model was statistically significant in hypothesis testing of $\mathrm{H}_{03}$ : Employee involvement has no significant influence on employee engagement in parastatals in the energy sector in Kenya

Table 4 (b): Regression ANOVA for Employee Involvement and Employee Engagement

\begin{tabular}{|c|c|c|c|c|c|c|}
\hline \multicolumn{7}{|c|}{ ANOVA $^{\mathbf{a}}$} \\
\hline Model & & $\begin{array}{l}\text { Sum of } \\
\text { Squares }\end{array}$ & $\mathrm{Df}$ & Mean Square & $\mathrm{F}$ & Sig. \\
\hline \multirow[t]{3}{*}{1} & Regression & 7.825 & 1 & 7.825 & 58.203 & $.000^{\mathrm{b}}$ \\
\hline & Residual & 22.049 & 164 & .134 & & \\
\hline & Total & 29.875 & 165 & & & \\
\hline \multicolumn{7}{|c|}{ a. Dependent Variable: Employee Engagement } \\
\hline \multicolumn{7}{|c|}{ b. Predictors: (Constant), Employee Involvement } \\
\hline
\end{tabular}




\section{Regression coefficients for employee involvement and employee engagement}

Table 4 (c): Regression coefficients for employee involvement and employee engagement

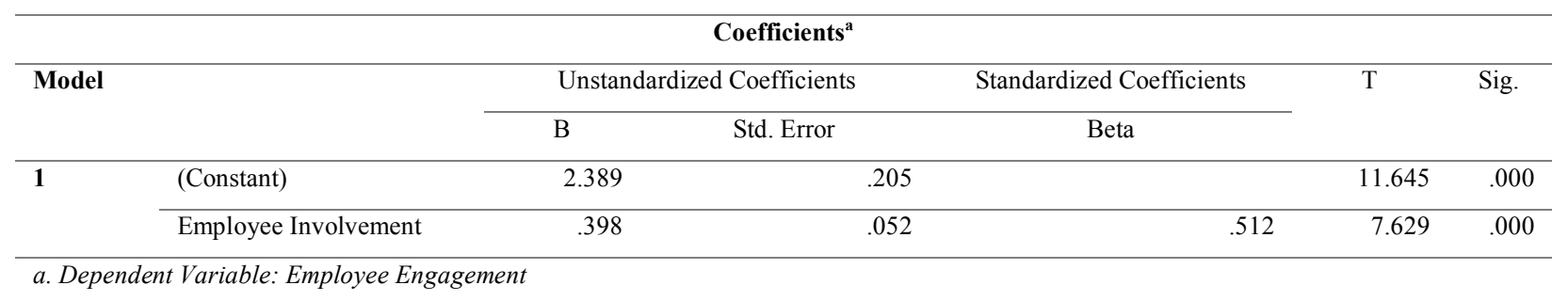

The results in Table 4 (c) indicate that employee involvement positively and significantly predicted employee engagement, $\beta=0.398$, $t(165)=58.203, p<.01$. This implies that a unit increase in employee involvement would lead to a significant increase in employee engagement among middle level managers in parastatals in the energy sector in Kenya by $39 \%$ and reduced employee involvement will equally reduce the engagement. The results of the multiple linear regression in Tables 4 (a), (b) and (c) show that employee involvement significantly predicted employee engagement of middle level managers as illustrated by $R^{2}=.262, F(1,165)=58.203$, $p<.05, \beta=0.398, t(165)=7.629, p<.01$, hence the null hypothesis $\mathrm{H}_{03}$ : Employyee Involvement has no significant influence on employee engagement in parastatals in the energy sector in Kenya, was rejected.

\section{Multiple linear regression analysis and hypothesis testing for employee motivation and employee engagement}

Using multiple linear regression, the study tested the moderating role of employee motivation on the relationship between intellectual stimulation and employee engagement. This was conducted to test the following hypothesis:

$\mathrm{H}_{04}$ : Employee Motivation does not significantly moderate the relationship between intellectual stimulation and employee engagement in parastatals in the energy sector in Kenya.

Based on the coefficients in Table 5, the predictor variables (intellectual stimulation) explained 37.4\% of the variation in engagement of middle level managers in parastatals in the energy sector in Kenya. The last test entailed testing the moderating effect of employee motivation on the relationship between intellectual stimulation of the top management and the engagement of middle level managers. From the results, the variation in $R^{2}$ indicates a positive change where the variability attributed by the predictor variables increased from $37.4 \%\left(R^{2}=0.374\right)$ to $40.9 \%\left(R^{2}=0.409\right)$. Based on the coefficients in model 2 , the predictor variable (intellectual stimulation and Employee Motivation) explains $64 \%$ of the variation in employee engagement of middle level managers in parastatals in the energy sector in Kenya, $R=.640$. Testing the moderating effect of employee motivation showed a significant influence on the relationship between intellectual stimulation and employee engagement, $\beta=.259, t=3.086, p<.01$.

Table 5: Multiple Linear Regression Analysis of Employee Motivation as a Moderator

\begin{tabular}{|c|c|c|c|c|c|c|c|c|c|}
\hline \multicolumn{10}{|c|}{ Model Summary } \\
\hline \multirow[t]{2}{*}{ Model } & \multirow[t]{2}{*}{$\mathrm{R}$} & \multirow[t]{2}{*}{ R Square } & \multirow{2}{*}{$\begin{array}{l}\text { Adjusted R } \\
\text { Square }\end{array}$} & \multirow{2}{*}{$\begin{array}{l}\text { Std. Error of } \\
\text { the Estimate }\end{array}$} & \multicolumn{5}{|c|}{ Change Statistics } \\
\hline & & & & & $\begin{array}{l}\text { R Square } \\
\text { Change }\end{array}$ & F Change & df1 & df2 & $\begin{array}{l}\text { Sig. F } \\
\text { Change }\end{array}$ \\
\hline \multicolumn{2}{|l|}{1} & .374 & .370 & .339 & .374 & 95.611 & 1 & 160 & .000 \\
\hline \multicolumn{2}{|l|}{2} & .409 & .402 & .331 & .035 & 9.525 & 1 & 159 & .002 \\
\hline \multicolumn{10}{|c|}{ a. Predictors: (Constant), Intellectual Stimulation } \\
\hline \multicolumn{10}{|c|}{ b. Predictors: (Constant), Intellectual Stimulation, Motivation } \\
\hline \multicolumn{10}{|c|}{ ANOVAa } \\
\hline \multicolumn{2}{|l|}{ Model } & \multicolumn{2}{|c|}{ Sum of Squares } & $\mathrm{Df}$ & \multicolumn{2}{|c|}{ Mean Square } & $\mathrm{F}$ & \multicolumn{2}{|c|}{ Sig. } \\
\hline \multirow[t]{3}{*}{1} & Regression & & 11.017 & 1 & & 11.017 & 95.611 & & $.000^{\mathrm{b}}$ \\
\hline & Residual & & 18.436 & 160 & & .115 & & & \\
\hline & Total & & 29.452 & 161 & & & & & \\
\hline \multirow[t]{3}{*}{2} & Regression & & 12.059 & 2 & & 6.029 & 55.115 & & $.000^{\mathrm{c}}$ \\
\hline & Residual & & 17.394 & 159 & & .109 & & & \\
\hline & Total & & 29.452 & 161 & & & & & \\
\hline \multicolumn{10}{|c|}{ a. Dependent Variable: Employee Engagement } \\
\hline \multicolumn{10}{|c|}{ b. Predictors: (Constant), Intellectual Stimulation } \\
\hline
\end{tabular}




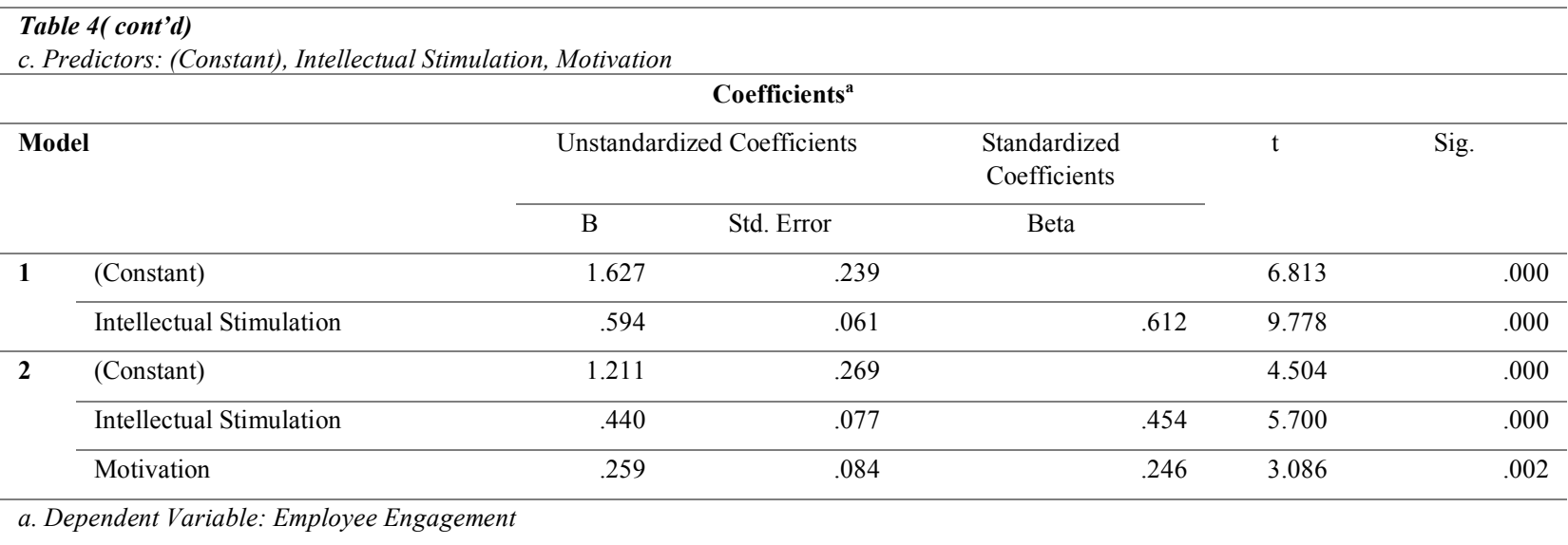

The findings of the multiple linear regression in Tables 5 established that employee motivation significantly influenced the relationship between intellectual stimulation of the top management and employee engagement of middle level managers as indicated by $R^{2}=.405, F(2,159)=54.100, p<.05 ; \beta=0.259, p<.01$. This implied the rejection of the null hypothesis $\mathrm{H}_{04}$ : Employee motivation does not significantly moderate the relationship between intellectual stimulation and employee engagement.

\section{Conclusions}

The first objective of this study was to establish the influence of creativity and innovation on employee engagement in parastatals in the energy sector in Kenya. The study, using multiple linear regression found that when leaders encourage creativity and innovation employee engagement of followers is enhanced as shown by $R^{2}=.291, F(1,165)=67.364, p<.0 .05, \beta=0.403, t(165)=8.208, p<$ .01 . The findings found favor with those of Ghodratolla et al. (2013) who depicted that through creativity and innovation, employees generate new ideas for new products, services and solutions to problems and by this employee engagement and overall performance of the organization in enhanced. Similarly, Mafini (2015) found that innovation within organizations enhances the performance of employees in South Africa. Also, these findings mirror those of Wambui et al. (2018) who established that leaders who encourage creativity and innovation have a highly performing workforce.

In addition, the findings revealed that job design significantly predicts employee engagement as shown by $R^{2}=.204, F(1,165)=$ $41.998, p<.0 .05, \beta=.361, t(165)=6.481, p<.01$. This mirrors the findings of Jones et al. (2017) who found that job design significantly predicts employee engagement. The findings also echo those of Truss (2012) who found that job design has a positive relationship with employee engagement. Crawford et al (2013) confirmed that when employees are assigned challenging and interesting roles, they are inspired and motivated to devote their efforts in their work, enhancing employee engagement Similarly, Obianuju and Nsoedo (2015) found a positive relationship between job design and employee engagement. The findings also mirror those of Kariuki and Makori who found that job design predicts employee engagement.

Also, using multiple linear regression analysis, the study found that employee involvement positively and significantly predicted employee engagement as indicated by $R^{2}=.262, F(1,165)=58.203, p<.0 .05, \beta=0.398, t(165)=7.629, p<.01$. Similarly, Thavakumar and Evangeline (2016) found that when employees participate and are involved in decision making processes within the organization, employee engagement is enhanced. These findings agree with those of Ike et al. (2017) who found that leaders who encourage their followers' involvement have a highly committed work force These findings also echo those of Applebaum et al. (2013) who found that employee involvement enhances the commitment of employees towards their work. These findings found favor with those of Butali and Njoroge (2015) who established that employee involvement significantly predicts employee engagement.

This study examined how employee motivation moderates the relationship between intellectual stimulation and employee engagement in parastatals in the energy sector in Kenya. The findings of the study revealed that employee motivation significantly moderates between intellectual stimulation and employee engagement as illustrated by $R^{2}=.405, F(2,159)=54.100, p<.0 .05, \beta=$ $0.259, p<.01$. The findings agree with those of Society for Human Resource Management (2013) who suggested that extrinsic rewards motivate, engage and retain employees. The findings confirmed those of Dysik and Kuvaas (2014) who determined that when employees receive intrinsic rewards from their jobs, they are motivated to perform beyond expectations. This also confirms the findings of Lee and Hidayat (2018) who found that intrinsic motivation moderates the relationship between transformational leadership and employee performance. The findings also agree with those of Naile and Selesho (2014) who found that motivation is one of the moderating variables that strengthen the effectiveness between leadership and employee engagement. 


\section{References}

Abbas, G., Iqbal, J., Waheed, A. \& Riaz, M. N. (2012). Relationship between transformational leadership style and innovative work behavior in educational institutions. Journal of Behavioral Sciences, 22(3).

Abid, A. M., Sarwar, A., Imran, K., Jabbar, A. \& Hanna, A. (2013). Effect of Job Design on Employee satisfaction (A Study of Fertilizer Companies listed in Lahore Stock Exchange). European Journal of Business and Management, 5(19).

Afande, F. O. (2015). Factors Affecting Levels of Customer Satisfaction in Government Parastatals in Kenya (A Case of Kenya Power). Journal of Marketing and Consumer Research, 9.

Alalade, S. Y. \& Oguntodu, J. A. (2015). Motivation and Employees' Performance in The Nigerian Banking Industry: A Survey of Selected Banks. International Journal of Economics, Commerce and Management, 3(4).

Albercht, S. L., Bakker, A. B., Gruman, J. A., Macey, W. H., \& Saks, A. M. (2015). Employee engagement, human resource management practices and competitive advantage: An integrated approach. Journal of Organizational Effectiveness: People and Performance, 2, 7- 35. doi:10.1108/joepp-08-2014-0042.

Alghazo, M. A. \& Al-Anazi, M. (2016). The Impact of Leadership Style on Employee Motivation. International Journal of Economics and Business Administration, 2(5).

Alvi, A. K., Kahn, M. A., Ahmed, A. A. \& Zulfiqar, M. (2014). A study of Employee Compensation and Employee Job Engagement on banks of Lahore, Pakistan. Science International (Lahore), 26(5), 2411-2414.

Amabile, T.M. (2013). Componential Theory of Creativity. Encyclopedia of Management Theory, Sage Publications.

Anjali, D., Cvb, C. V., Vijayanand, V. \& Ganesgkumar, P. T. (2017). The impact of employee engagement on discretionary effort and intention to turnover among HR professionals in manufacturing sector-an empirical study. International Journal of Applied Business and Economic Research, 15(7).

Applebaum, S. H., Louis, D., Makarenko, D., Saluja, J., Maleshko, O. \& Kulbashian, S. (2013). Participation in decision making: a case study of job satisfaction and commitment (part one). Industrial and Commercial Training, 45(4).

Aroosiya, M. A. C. F. \& Ali, M. A. M. H. (2014). Impact of job design on employees' performance (with special reference to school teachers in the Kalmunai Zone). Journal of Management, 8(1), pp.33-41.

Asfar, B., Badir, Y. F., Saeed, B. \& Hafeez, S. (2017). Transformational and transactional leadership and employee's entrepreneurial behavior in knowledge-intensive industries. The International Journal of Human Resource Management, 28(2).

Aunjum, A. H., Abbas, G. \& Sajid, M. (2017). Transformational Leadrship and Employee Motivation in Banking Sector of Pakinstan. Advances in Economics and Business, 5(9).

Bass, B. M. (1985). Leadership performance beyond expectations. Academic Press, New York.

Bass, B. M. (1990). From transactional to transformational leadership: Learning to share the vision. Organizational Dynamics, 18(3), $19-31$.

Bass, B. M. \& Bass, R. (2008). The Bass handbook of leadership: Theory, research, and managerial applications (4th ed.). New York: Free Press.

Bass, B. M. \& Riggio, R. E. (2006). Transformational leadership (2nd ed.). Mahwah, NJ, US: Lawrence Erlbaum Associates Publishers.

Batista-Taran, L. C., Shuck, M. B., Gutierrez, C. C., \& Baralt, S. (2013). The role of leadership style in employee engagement. In M. S. Plakhotnik, S. M. Nielsen, \& D. M. Pane (Eds.), Proceedings of the Eighth Annual College of Education \& GSN Research Conference (pp. 15-20). Miami: Florida International University. http://coeweb.fiu.edu/research_conference/

Bersin, J. (2014, March 15). Why companies fail to engage today's workforce: The overwhelmed employee. Forbes. Retrieved from https://www.forbes.com/sites/joshbersin/2014/03/15/why- companies-fail-to-engage-todays-workforce-the-overwhelmedemployee/\#34880e894726

Bundi, S. M., Lewa, P. \& Ndwiga, M. (2015). Managers in State Owned Enterprises (SOEs) in Kenya. European Journal of Business and Management, $7(36)$.

Burns, J. M. (1978). Leadership. New York: Harper and Row.

Chaudhuri, S. \& Bartlett, K. R. (2012). The relationship between training outsourcing and employee commitment to organization. Human Resource Development International, 17(2)

Conger, J. A. (2014). Charismatic leadership in organizations. Thousand Oaks, California. Sage Publications.

Crawford, E., Rich, B., Buckman, B. \& Bergeron, J. (2013). The Antecedents \& Drivers of Employee Engagement, in Truss, C., Alfes, K., Delbridge, R., Shantz, A \& Soane, E. (2013). Employee Engagement in Theory and Practice. London: Routledge.

Dabas, D. \& Pandey, N. (2015). Role of Self Efficacy and Intrinsic Motivation on Work Place Environment. International Journal of Education and Psychological Research, 4(1).

Dasgupta, M. (2015). Middle Level Managers and Strategy: Exploring the Influence of Different Roles on Organisational Performance. Journal of General Management, 41(1).

Datche, E. A. \& Mukulu, E. (2015). The effects of transformational leadership on employee engagement: A survey of civil service in Kenya. Issues in Business Management and Economics, 3(1).

Dickson, J., Kirkpatrick-Husk, K., Kendall, D., Longabaugh, J., Patel, A. \& Scielzo, S. (2014). Untangling prote' ge' self-reports of mentoring functions: further meta-analytic understanding. Journal of Career Development, 41, pp. 263-281. 
Dysvik, A. \& Kuvaas, B. (2011). Intrinsic motivation as a moderator on the relationship between perceived job autonomy and work performance. European Journal of Organizational Psychology, 20, 367-387.

Elsele, L., Gronhert, T., Bausaert, S., \& Segers, M. R. (2013). Employee Motivation for Personal Development Plan Effectiveness. International Journal of Training and Development, 37(6).

Fauji, M. \& Utami, M. (2013). How Intellectual Stimulation Effects Knowledge Sharing, Innovation and Firm Performance. International Journal of Social Science and Humanity, 3(4).

Froiland, J. M., \& Worrell, F.C. (2016). Intrinsic motivation, learning goals, engagement, and achievement in a diverse high school. Psychology in the Schools, 53, 321-336.

Gabbar, H. A., Honarmand N. \& Abdelsalam A. A. (2014). Transformational leadership and its impact on governance and development in African nations: Ananalytical approach. Journal of Entrepreneurship \& Organization Management, $3(121)$.

Ganta, V. C. (2014). Motivation in the workplace to Improve the employee performance. International Journal of Engineering Technology, Management and Applied Sciences, 2(6).

Gautam, A. \& Enslin, E. (2019). Transformational Leadership and Work Engagement in the Automotive Retail Industry: A Study of South Africa. International Business Research, 12(5).

Gennaro, D. (2018). Transformational leadership for public service motivation. Journal of Economic and Administrative Sciences, 35(1).

Ghodratollah, B., Mahdi, E., Ahmad, A. \& Reza, S. (2013). An analysis of the effect of individual creativity on the employees' engagement at work (Case study: Agriculture organization of QOM). International Journal of Accounting Research, 1(2).

Gerst R. (2013). Understanding Employee Engagement and Trust; The New Math of Engagement Surveys', The Journal for Quality and Participation, 32-36

Ghodratollah, B., Mahdi, E., Ahmad, A. \& Reza, S. (2013). An analysis of the effect of individual creativity on the employees' engagement at work (Case study: Agriculture organization of QOM). International Journal of Accounting Research, 1(2).

Grote, G. \& Guest, D. (2016). The case for reinvigorating quality of working life research. Human Relations, 70(2).

Guest, D. (2014). Employee Engagement: a skeptical analysis. Journal of Organizational Effectiveness: People and Performance, 1(2),

Gyamfi, G. (2014). Influence of Job Stress on Job Satisfaction: Empirical Evidence from Ghana Police Service. International Business Research, 9.

Gyamfi, G. D. (2015). Assessment of the Relationship between Employee Motivation and Employee Performance at a Bank in Ghana. International Journal of Economics, Commerce and Management, 3(3).

Hawkes, A. J., Biggs, A. \& Hegerty, E. (2017). Work Engagement: Investigating the Role of Transformational Leadership, Job Resources, and Recovery. The Journal of Psychology, 151(6).

Hayati, D., Charkhabi, M., \& Naami, A. (2014). The relationship between transformational leadership and work engagement in governmental hospitals nurses: a survey study. SpringerPlus, 3, 25. http://doi.org/10.1186/2193-1801-3-25.

Humborstad, S. I. W., Nerstad, C. G., \& Dysvik, A. (2014). Empowering leadership, employee goal orientations and work performance: A competing hypothesis approach. Personnel Review, 43(2), 246-271

IBM (2014). Beyond engagement: The definitive guide to employee surveys and organizational performance. http://www01.ibm.com/common/ssi/cgibin/ssialias?infotype=SA\&subtype=WH\&htmlfid=LOW14043USEN

Ike, P. R., Ezeh, L. N. \& Etodike, C. E. (2017). Employee Participation in Decision Making: A Correlate of Employee Citizenship Behavior and Counterproductive Workplace Behavior. International Journal of Academic Research in Business and Social Sciences, 7(7).

Iqbal, T., Khan, K. \& Iqbal, N. (2012). Job stress and employee engagement. European Journal of Social Sciences, 28(1): $109-118$. Irshad, A. (2016). Impact of Extrinsic Rewards on Employees' Performance. Journal of Global Economics, 4(3).

Ismail, H. N., Iqbal, A. \& Nasr, L. (2019). Employee engagement and job performance in Lebanon: the mediating role of creativity. International Journal of Productivity and Performance Management, 68(3).

Irawanto, D. W. (2015). Employee participation in decision-making: Evidence from a state-owned enterprise in Indonesia. Management, 20(1).

Izlem, G. \& Omer, S. (2015). Role of Leadership in Employees' Work Engagement: Organizational Identification and Job Autonomy. International Journal of Business and Management, 11(1).

Jansen, A. \& Samuel, M. O. (2014). Achievement of Organisational Goals and Motivation of Middle Level Managers within the Context of the Two-Factor Theory. Meditarranean Journal of Social Sciences, 5(16).

Jensen, J. D. (2018). Employee Motivation: A Leadership Imperative. International Journal of Business Administration, 9(2).

Jensen, U. T. \& Bro, L. L. (2017). How Transformational Leadership Supports Intrinsic Motivation and Public Service Motivation: The Mediating Role of Basic Need Satisfaction. American Review of Public Administration, 48(6) 535-549.

Jones, A. M. \& York, S. L. (2017). The Fragile Balance of Power and Leadership. The Journal of Values-Based Leadership, 9(2).

Kariuki, N. \& Makori, M. (2015). The Role of Job Design on Employee Engagement in Private Universities in Kenya: A case of Presbyterian University of East Africa. The Strategic Journal of Business and Change Management, 2 (60),365-385. 
Kaul, S. (2017). Relationship between transformational leadership and employee engagement in public sector enterprises: Review of literature and proposed research agenda Journal of Management \& Research, 11(4).

Khuong, M. N. \& Nguyen, H. U. (2016). Factors Affecting Employee Job Engagement towards Aircraft Maintenance Organizations. A Mediation Analysis of Job Satisfaction. Journal of Economics, Business and Management, 4(4).

Kortmann, S., Gelhard, C., Zimmermann, C., \& Piller, F. (2014). Linking strategic flexibility and operational efficiency: The mediating role of ambidextrous operational capabilities. Journal of Operations Management, 32, 475-490. doi:10.1016/j.jom.201.09.007

Lawler, E. J. (2003). Reward Practices and Performance Management System Effectiveness. Organizational Dynamics, 32(4).

Lee, C. \& Hidayat, N. (2018). The Influence of Transformational Leadership and Intrinsic Motivation to Employee Performance. Advances in Management and Applied Economics, 8(2).

Mafini, C. (2015). Predicting Organisational Performance Through Innovation, Quality And Inter-Organisational Systems: A Public Sector Perspective. The Journal of Applied Business Research, 31(3).

Mansor, Z. D., Mun, C. P., Farhana, B. S. \& Tarmizi, W. A. N. (2017). Influence of Transformation Leadership Style on Employee Engagement among Generation Y. International Journal of Economics and Management Engineering, 11(1).

Masvaure, P., Ruggunan, S. \& Maharaj, A. (2014). Work Engagement, Intrinsic Motivation and Job Satisfaction among Employees of a Diamond Mining Company in Zimbabwe. Journal of Economics and Behavioral Studies, 6(6).

Mbithi, A. M., K'Obonyo, P.O. \& Awino, Z. B. (2016). Transformational Leadership, Employee Outcomes and Performance of Universities in Kenya. 2ND DBA-AMR International Conference, Conference proceedings, School of Business, University of Nairobi.

McCleskey, J. A. (2014). Situational, transformational, and transactional leadership and leadership development. Journal of Business Studies Quarterly, 5(4), 117.

Mehmood, S., Ramzan, M. \& Akbar, M. T. (2013). Managing Performance through Reward System. Journal Of Humanities And Social Science, 15(2).

Mohanan, M., Sequeira, A. H. \& Kumar, M. S. (2012). Employee Engagement and Motivation: A Case Study. Journal of Indian Management Research and Practices. https://ssrn.com/abstract=2114214 or http://dx.doi.org/10.2139/ssrn.2114214

Miring'u, A. \& Muoria, E. (2011). An analysis of the effect of Corporate Governance on performance of Commercial State Corporations in Kenya. International Journal of Business and Public Management, 1, 36-41.

Murage, S. N., K'Aol, G. O. \& Njenga, K. (2017). Effect of intellectual stimulation and individualized consideration of the CEO on performance in the private sector in Kenya. Human Resource and Leadership Journal, 2(3).

Mozammel, S. \& Haan, P. (2016). Transformational leadership and Employee Engagement in the Banking sector in Bangladesh. Journal of Developing Areas Special Issue, 50, 43- 55.

Muchiri, M., Cooksey, R. W. \& Walumbwa, F. O. (2012). Transformational and Social Processes of Leaders as predictors of organizational outcomes. Leadership \& Organization Development Journal, 33(13), 355-376.

Naile, I., \& Selesho, J. M. (2014). The Role of Leadership in Employee Motivation. Mediterranean Journal of Social Sciences, 5(3).

Ndwiga, M. \& Ngaithe, L. (2016). The Effect of Individualized Consideration and Intellectual Stimulation on Organizational Performance of Commercial State-Owned Enterprises in Kenya. Journal of Economics and Sustainable Development, vol. $7(20)$.

Ngaithe, L., K'Aol, G., Lewa, P. \& Ndwiga, M. (2016). Effect of Idealized Influence and Inspirational Motivation on Staff Performance in State Owned Enterprises in Kenya. European Journal of Business and Management, 8(30).

Nguwi, M. (2011). Work Engagement Trends in Zimbabwe. Financial Gazette http://allafrica.com/stories/201012220113.html Accessed 5 February 2016

Osmani, J. (2016). Are Groups the Best Way to Make Decisions? A Literature Review.Academic Journal of Interdisciplinary Studies, $5(1)$.

Popli, S. \& Rizvi, I. (2016). Drivers of Employee Engagement: The Role of Leadership Style. Global Business Review, 17(4).

Rezvani, Z. (2017). Who is a Middle Manager: A literature Review.International Journal of Family Business Management, 1(2): 19

Ryan, R. M., Deci E. L. (2017). Self-determination theory: Basic Psychological Needs in Motivation Development and Wellness. New York, NY: Guilford Press.

Saboe, K. N., Taing, M. U., Way, J. D., \& Johnson, R. E. (2015). Examining the unique mediators that underlie effects of different dimensions of transformational leadership. Journal of Leadership \& Organizational Studies, 22, 175-186.

Saumya, M. \& Ritu, S. (2015). Impact of Effective Leadership on Employee Engagement. International Journal of Education and Management Studies, 5(2).

Sartono, H. \& Ardhani, M. (2015). Work Engagement, Intrinsic Motivation and Job Satisfaction among Employees of a Coal Mining Company in South Borneo. International Journal of Business Studies, 8 (2). 
Shantz, A., Alfes, K., Bailey, C. \& Soane, E. (2013). The role of employee engagement in the relationship between job design and task performance, citizenship and deviant behaviors. International Journal of Human Resource Management, 24(13), 2608 $-2627$.

Shantz, A., Alfes, K., Soane, E., \& Truss C. (2013). A Theoretical and Empirical Extension of the Job Characteristics Model. International Journal of Human Resource Management, 23(13).

Sharma, D. \& Krishnan, V. R. (2012). The Impact of Pay Satisfaction and Transformational Leadership on Employee Engagement. International Journal of Management and Behavioral Sciences, vol. 3(2).

Sharma, P. (2016). Effect of Intellectual Stimulation on Creativity of Engineers Working in Automotive Sector In India. International Journal of Management and Applied Science (IJMAS, 2(5).

SHRM (2013). Employee job satisfaction and engagement. Revitalizing a Changing Workforce. Retrieved from www.shrm.org

Shuck, B., \& Herd, A. 2012. Employee engagement and leadership: Exploring the convergence of two frameworks and implications for leadership development in HRD. Human Resource Development Review, 11(2), 156-181.

Singh, R. (2016). The Impact of Intrinsic and Extrinsic Motivators on Employee Engagement in Information Organizations. Journal of Education for Library and Information Science, 57(2).

Smith, E., Joubert, P. \& Karodia, A. M. (2015). The impact of intrinsic and extrinsic rewards on employee motivation at a medical devices company in South Africa. Arabian Journal of Business and Management Review, 5(1).

Soliha, E., Dharmmesta, B. S., Purwanto, B. M. \& Syahlani, S. P. (2014). Message Framing, Source Credibility, and Consumer Risk Perception with Motivation as Moderating Variable in Functional Food Advertisements. American International Journal of Contemporary Research, 4(1) 193-208.

Sougui, A. O., Bon, A. T., Mahamat, M. A. \& Hassan, H. M. (2016). The Impact of Leadership on Employee Motivation in Malaysian Telecommunication Sector. Galore International Journal of Applied Sciences and Humanities, 1(1).

Susilo, D. (2018). Transformational Leadership; A Style of Motivating Employees. Management and Economics Journal, 2(2).

Swathi, S. (2013). Impact of Leadership on Employee Engagement. International Journal of Marketing, Financial Services \& Management Research, 2(5).

Tao, Y. M. \& Kang, Y. (2012). The Relationship Study Based on the Organizational Commitment between Organizational Innovation Climate and Individual Innovation Behavior. Industrial Technology and Economy, 6,145-150.

Thavakumar, D. \& Evangeline, S. J. (2016). The influence of Involvement and participation, compensation, communication and work-life balance on Employee Engagement: A Case of Insurance Companies in Batticaloa District. International Journal of Multidisciplinary Studies (IJMS), 3(1).

Truss, C. (2012). Spinning Plates and Juggling Hats: Employee Engagement in an Era of Austerity'. Wimbledon: CIPD.

Vandenabeele, W. (2014). Explaining public service motivation: The role of leadership and basic needs satisfaction. Review of Public Personnel Administration, 34, 153-173. doi:10.1177/0734371x14521458

Wambui, S. K., Kahuthia, J. \& Gakenia, J. (2018). Innovation Strategies and Organizational Performance: A Case Study of Telkom Kenya Limited. Strategic Journal of Business and Change Management, 5(3).

Wachira, J. M. (2013). Relationship between employee engagement and commitiment in Barclays Bank of Kenya. Unpublished Masters Theses UoN.

Yousaf, S., Latif, M., Aslam, S. \& Saddiqui, A. (2014). Impact of Financial and non- Financial Rewards on Employee Motivation. Middle-East Journal of Scientific Research, 21 (10)

Zubair, A., Bashir, M., Abrar, M., Baig, S. A. \& Hassan, S. Y. (2015). Employee's Participation in Decision Making and Manager's Encouragement of Creativity: The Mediating Role of Climate for Creativity and Change. Journal of Service Science and Management, 8, 306-321.

Zameer, H., Ali, S., Nisar, W. \& Amir, M. (2014). The Impact of the Motivation on the Employee's Performance in Beverage Industry of Pakistan. International Journal of Academic Research in Accounting, Finance and Management Sciences, 4(2). 